\title{
Intrahepatic bile duct dilation and gallbladder hydrops due to a cystic duct stenosis in a 2-month-old boy
}

\author{
André Lollert, Katharina Laudemann, Gundula Staatz
}

Department of Diagnostic and Interventional Radiology, Section of Pediatric Radiology, Medical Center of the Johannes Gutenberg University, Mainz, Rhineland-Palatinate, Germany

\section{Correspondence to} Dr André Lollert, andre.lollert@unimedizinmainz.de

Accepted 23 April 2015
CrossMark

\section{To cite: Lollert $A$,} Laudemann K, Staatz G. BMJ Case Rep Published online: [please include Day Month Year] doi:10.1136/ bcr-2015-209385

\section{DESCRIPTION}

A 2-month-old boy presented with slight diffuse abdominal pain after an uncomplicated pregnancy and perinatal period. Height $(62 \mathrm{~cm})$ and weight $(5.5 \mathrm{~kg})$ were according to the age. Routine blood tests showed no abnormalities except for a minimal elevation of aspartate aminotransferase to 38 units/ L (reference range 5-35 U/L). Primary abdominal ultrasound showed a dilation of the common bile duct and a gallbladder hydrops (figure 1). MR cholangiopancreatography (MRCP) was indicated to detect the cause for these incidental findings. Contrary to normal bile ducts in small infants, ${ }^{1}$ the dilated bile duct system can be reliably imaged using $\mathrm{MRCP}^{2} \mathrm{~A}$ heavily T2-weighted respiratorygated MRCP sequence (T2-space) was performed on a $3 \mathrm{~T}$ scanner and revealed a stenosis of the distal cystic duct with a consecutive dilation of its proximal part as the cause for the hydrops. The dilated cystic duct compressed the common bile duct, which also led to intrahepatic bile duct dilation (figure 2). A conservative approach has not been reported very often in the literature, but could prevent unnecessary surgery in some cases. ${ }^{3}$ It was assumed that this pathology has a significant probability to resolve during growth. Cholecystectomy was assumed unnecessary due to nearly normal laboratory parameters as well as no clinically relevant symptoms. Ultrasound follow-up examinations were planned. The most recent examination at the age of 16 months showed a significant regression of the gallbladder size and the common bile duct was only slightly accentuated with a maximum width of approximately $2.3 \mathrm{~mm}$.

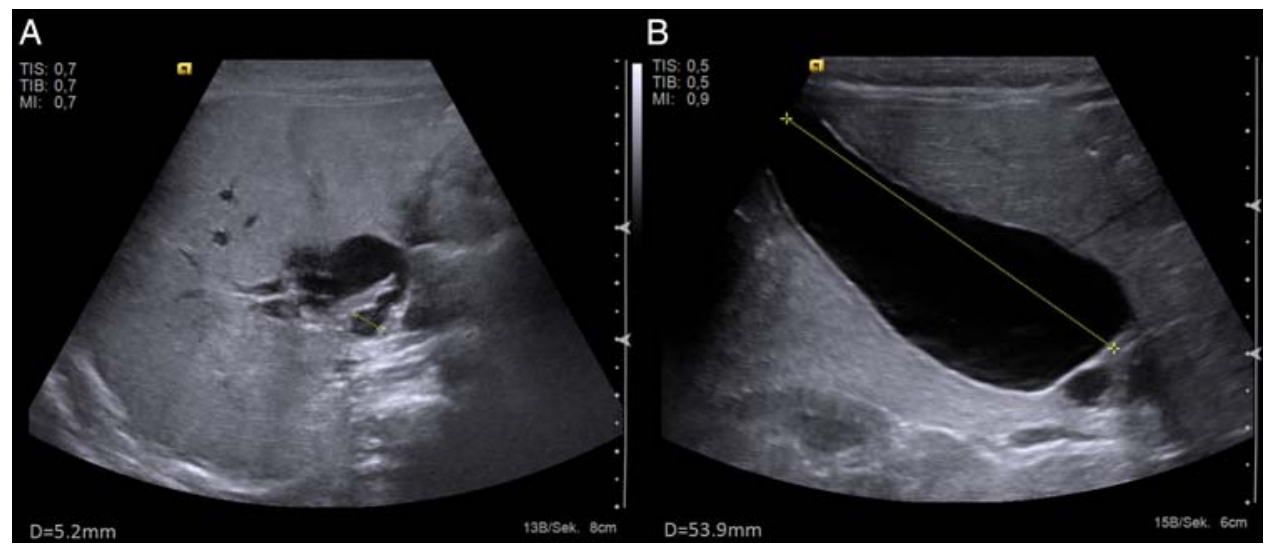

Figure 1 Abdominal ultrasound, showing a dilation of the common bile duct to approximately $5.2 \mathrm{~mm}(\mathrm{~A})$, and a gallbladder hydrops (B).

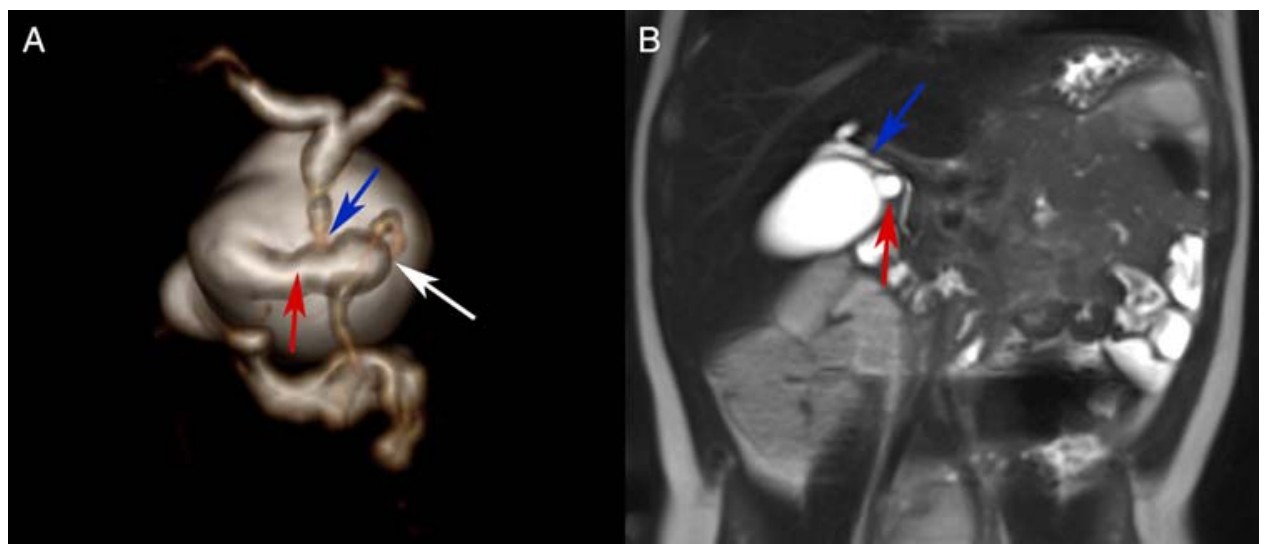

Figure 2 Three-dimensional (A) and T2-weighted coronal MR cholangiopancreatography (B) showing a stenosis of the distal cystic duct (white arrow) with a consecutive dilation of its proximal part (red arrow) as the cause for the gallbladder hydrops. The dilated cystic duct (red arrow) compresses the common bile duct (blue arrow), which also leads to intrahepatic bile duct dilation. 
Learning points

A well-indicated MR cholangiopancreatography (MRCP) can accurately image bile duct pathologies even in very small children, if primary ultrasound shows dilated bile ducts. MRCP can therefore lead to therapeutic decisions including indication or cancellation of possibly more invasive diagnostics and/or therapies.

- An ultrasound examination of the abdomen with special focus on the bile duct system should always be performed prior to a sedation-requiring MRI as non-dilated bile ducts cannot be reliably imaged using MRCP.
Competing interests None declared.

Patient consent Obtained.

Provenance and peer review Not commissioned; externally peer reviewed.

\section{REFERENCES}

1 Siles $\mathrm{P}$, Aschero A, Gorincour G, et al. A prospective pilot study: can the biliary tree be visualized in children younger than 3 months on magnetic resonance cholangiopancreatography? Pediatr Radiol 2014;44:1077-84.

2 Egbert ND, Bloom DA, Dillman JR. Magnetic resonance imaging of the pediatric pancreaticobiliary system. Magn Reson Imaging Clin N Am 2013:21:681-96.

3 Gasparetto M, Giordano L, Cananzi M, et al. Conservative treatment for cystic duct stenosis in a child. Case Rep Hepatol 2013;2013:146261.

Copyright 2015 BMJ Publishing Group. All rights reserved. For permission to reuse any of this content visit http://group.bmj.com/group/rights-licensing/permissions.

BMJ Case Report Fellows may re-use this article for personal use and teaching without any further permission.

Become a Fellow of BMJ Case Reports today and you can:

- Submit as many cases as you like

- Enjoy fast sympathetic peer review and rapid publication of accepted articles

- Access all the published articles

- Re-use any of the published material for personal use and teaching without further permission

For information on Institutional Fellowships contact consortiasales@bmjgroup.com

Visit casereports.bmj.com for more articles like this and to become a Fellow 